\title{
Influence of tied-ridge-furrow with inorganic fertilizer on grain yield across semiarid regions of Asia and Africa: a meta- analysis
}

\author{
Erastus Mak-Mensah ${ }^{1}$, Peter Bilson Obour ${ }^{2}$, Qi Wang ${ }^{\text {Corresp. } 1}$ \\ ${ }^{1}$ College of Grassland Science, Gansu Agricultural University, Lanzhou, China \\ 2 Department of Geography and Resource Development, University of Ghana, Accra, Ghana \\ Corresponding Author: Qi Wang \\ Email address: 2873527446@qq.com
}

Background: In semiarid areas, low productivity of crops has been attributed to lack of appropriate soil moisture conservation practices since droughts and soil erosion are rampant in most areas of this region. Consequently, ridge-furrow rainwater harvesting is widely used in these regions across the globe. Despite ridge-furrow being widely practiced, tied-ridge-furrow has not been extensively adopted by small-scale farmers in semi-arid regions. Consequently, the effectiveness of tied-ridge-furrow as a viable method of increasing crop yield has received less attention.

Methodology: For large-scale implementation, a detailed assessment of how ridge furrow, tied-ridgefurrow with fertilizer, tied-ridge-furrow with mulching and tied- ridge-furrow without mulching or fertilizer influence crop yield in different agro-environments under varying climatic conditions is needed. This study used the PRISMA guidelines to determine the impact of tied-ridge-furrow rainwater harvesting technique with mulching on sorghum (Sorghum bicolor) and pearl millet (Pennisetum glaucum) grain yields.

Results: Sorghum grain yield increased by $17 \%$ greater in tied-ridge-furrow without mulching or fertilizer in comparison to flat planting. This may be due to increase in soil organic carbon in the region $\left(9 \mathrm{~g} \mathrm{~kg}^{-1}\right)$. Grain yield of millet significantly increased by 20 - 40\% in Africa from 18 study observations in tied-ridgefurrow with fertilizer application as compared to tied-ridge-furrow without mulching or fertilizer treatments. This might be due to the significant increase in total nitrogen by $13-42 \%$ in the soil at $<50$ $\mathrm{mg} \mathrm{kg}^{-1}$ quantity which had an effect size of 469.14 [65.60, 872.67]. In terms of soil texture, grain yield of millet and sorghum significantly increased in heavy textured soils (clay loam, silt clay, and clay soils) with an effect size of 469.14 [65.60, 872.67] compared to light and medium-textured soils of zero effect sizes. Millet and sorghum grain yields in tied-ridge-furrow with mulching, on the other hand, were not significantly different from those in flat planting. This may be due to the mulching materials used in those tests.

Conclusion: In view of yields of sorghum and millet increased significantly by 32 and $17 \%$ in tied-ridgefurrow without mulching or fertilizer treatment compared to flat planting and tied-ridge-furrow with fertilizer treatment compared with tied-ridge-furrow without mulching or fertilizer treatment, respectively, this study recommend the use of fertilizers in a tied-ridge-furrow system to increase grain yield in semiarid areas compared to flat planting. Again, the study recommends more research on tiedridge-furrow systems with other organic mulches and fertilizers in semiarid areas. 


\title{
Influence of tied-ridge-furrow with inorganic fertilizer on grain yield across semiarid regions of Asia and Africa: A meta-analysis.
}

\author{
Erastus Mak-Mensah ${ }^{1}$, Peter Bilson Obour², Qi Wang ${ }^{1 *}$ \\ ${ }^{1}$ College of Grassland Science, Gansu Agricultural University, Lanzhou, China \\ ${ }^{2}$ Department of Geography and Resource Development, University of Ghana, Accra, Ghana
}

Correspondence: Qi Wang ${ }^{1}$, Number 1 Yingmen Road, Anning District, Lanzhou, Gansu Province, China. Email address: 2873527446@qqq.com.

\begin{abstract}
Background: In semiarid areas, low productivity of crops has been attributed to lack of appropriate soil moisture conservation practices since droughts and soil erosion are rampant in most areas of this region. Consequently, ridge-furrow rainwater harvesting is widely used in these regions across the globe. Despite ridge-furrow being widely practiced, tied-ridge-furrow has not been extensively adopted by small-scale farmers in semi-arid regions. Consequently, the effectiveness of tied-ridge-furrow as a viable method of increasing crop yield has received less attention.
\end{abstract}

Methodology: For large-scale implementation, a detailed assessment of how ridge furrow, tiedridge-furrow with fertilizer, tied-ridge-furrow with mulching and tied- ridge-furrow without mulching or fertilizer influence crop yield in different agro-environments under varying climatic conditions is needed. This study used the PRISMA guidelines to determine the impact of tiedridge-furrow rainwater harvesting technique with mulching on sorghum (Sorghum bicolor) and pearl millet (Pennisetum glaucum) grain yields.

Results: Sorghum grain yield increased by $17 \%$ greater in tied-ridge-furrow without mulching or fertilizer in comparison to flat planting. This may be due to increase in soil organic carbon in the region $\left(9 \mathrm{~g} \mathrm{~kg}^{-1}\right)$. Grain yield of millet significantly increased by $20-40 \%$ in Africa from 18 study observations in tied-ridge-furrow with fertilizer application as compared to tied-ridgefurrow without mulching or fertilizer treatments. This might be due to the significant increase in total nitrogen by $13-42 \%$ in the soil at $<50 \mathrm{mg} \mathrm{kg}^{-1}$ quantity which had an effect size of 469.14 [65.60, 872.67]. In terms of soil texture, grain yield of millet and sorghum significantly increased in heavy textured soils (clay loam, silt clay, and clay soils) with an effect size of 469.14 [65.60, 872.67] compared to light and medium-textured soils of zero effect sizes. Millet and sorghum grain yields in tied-ridge-furrow with mulching, on the other hand, were not significantly different from those in flat planting. This may be due to the mulching materials used in those tests. 
37 Conclusion: In view of yields of sorghum and millet increased significantly by 32 and $17 \%$ in

tied-ridge-furrow without mulching or fertilizer treatment compared to flat planting and tiedridge-furrow with fertilizer treatment compared with tied-ridge-furrow without mulching or fertilizer treatment, respectively, this study recommend the use of fertilizers in a tied-ridgefurrow system to increase grain yield in semiarid areas compared to flat planting. Again, the study recommends more research on tied-ridge-furrow systems with other organic mulches and fertilizers in semiarid areas.

Keywords: Rainwater harvesting, Tied-ridging, Mulching, Fertilizer, Grain yield

\section{Introduction}

Globally, droughts characterized by low soil water availability and poor soil fertility are major factors limiting plant growth and yield (Olsovska et al., 2016). The problem is more severe in semiarid areas, which had been home to grain legumes (Hashem et al., 2019). This is due to the steepness of slopes and erosive nature of rainfall which make soil erosion severe in semi-arid lands (Wolka et al., 2018). Erosion depletes soil organic matter, which in turn decreases aggregate soil stability and water holding capacity which increases soil crusting (Wolka et al., 2018). In view of providing a lasting solution to this challenge, Mo et al. (2016) proposed an innovative, low-input, and high-yield farming practice called ridge-furrow rainwater harvesting system (RFRWHs).

In rain-fed agriculture, the RFRWH method has been beneficial and widely adopted by local farmers to increase crop water use efficiency (Eldoma et al., 2016, Yu et al., 2018, Zhang et al., 2018, Pan et al., 2019). The furrows created in RFRWH system can be left open, or closed at regular intervals for holding water and facilitating infiltration. Tied-ridges are formed in the field when the furrows are blocked with earth ties at predetermined distances to create a series of micro-catchment basins (Biazin \& Stroosnijder, 2012). Tied-ridging offers maximum potential for water conservation which can be useful to plants for a longer period (Ndlangamandla et al., 2016). Although RFRWH is a widespread tillage practice, tied-ridging has not been widely adopted by small-scale farmers in semi-arid regions (Jensen et al., 2003). Meanwhile, the adoption of soil moisture conservation techniques such as tied-ridges and mulching is reported to improve soil moisture retention (Ndlangamandla et al., 2016). Mulching could save $25 \%$ of water used in maize and wheat cultivation in rain-fed agriculture, according to Yan et al. (2015). Thus, there is an urgent need to explore improved water use and soil fertility management practices for optimal crop productivity in rain-fed agriculture in China (Andrew Tapiwa, 2019).

Besides drought, another factor constraining productivity in rain-fed agriculture is low soil fertility (Deng et al., 2006). The main ways to improve soil fertility include increasing soil organic matter by increasing the percentage of legume and green manure crops and combining this with the use of inorganic fertilizers. The use of crop residues as mulch and integrating them into the soil after crop harvest increases soil organic matter and fertilizer use efficiency (Deng et al., 2006). Inorganic fertilizers when applied as plant food, temporarily increases soil $\mathrm{pH}$ in the

PeerJ reviewing PDF | (2021:04:59828:3:1:NEW 9 Jul 2021) 
short-term, but can increase soil acidity in the long term due to nitrification of ammonium (Bährle-Rapp, 2007). Therefore understanding how plant biomass worldwide, particularly in Asia and Africa change with fertilizers and mulching applications in tied ridges is vital to harnessing their potential for large-scale implementation in agricultural production (Antala et al., 2020). Consequently, a more accurate method is required to estimate the effect sizes of fertilizer and mulch application practices in tied ridge-furrow on crop yield, WUE, and soil physical properties. Hence, meta-analysis was conducted to shed light on the influences of these practices, elucidates their impacts, and provides a new and more vigorous theoretical model.

Meta-analysis, fundamentally the 'analysis of analyses', is a method of quantitatively (a) recognizing overviews from a range of separate and disparate studies, and (b) determining inadequacies in existing research such that new preferences for future research can be proposed (Kuznetsov et al., 2008). Meta-analysis allows for statistical analysis of effect sizes and objective evaluation of other authors' experimental results (Mak-Mensah et al., 2021). Meta-analysis increases the statistical potential for evaluating theories and comparing treatment differences in various contexts (Luo et al., 2010). The effect size observed in each sample can be assumed to be an unbiased estimate of the underlying true effect size, subject to random variance. Metaanalysis can clarify trends in a quantitative way that in conventional reviews might be perceived as being biased by personal judgement (Verheijen et al., 2010). Research outcomes are coded into essential classifications for comprehensive discussion of both the status of scientific understanding on a specific 'effect', possible underlying mechanisms and marginal or exceptional conditions (Kuznetsov et al., 2008). Since so much depends on the quality of results that are to be synthesized, there is the danger that adherents may simply multiply the inadequacies of the data base and the limits of the sample (e.g. trying to compare the incomparable) (Kuznetsov et al., 2008). As new studies are published, meta-analyses on effect of tied-ridge-furrow with inorganic fertilizer on grain yield across semiarid regions of Asia and Africa can be updated (and refined) periodically once a large enough body of research has been established (Verheijen et al., 2010).

Although some field experiments have been conducted to assess the impact of fertilizer, yield and mulching use relationship in ridge-furrow rainwater harvesting system, no comprehensive, and quantitative analyses of available published data have been conducted thus far. Therefore, investigating grain yield across semiarid regions of Asia and Africa under the influence of tied-ridge-furrow with inorganic fertilizer is one of great importance to sustaining rain-fed agriculture on the Loess Plateau. Through a synthesis of existing results, the current study examined the impacts of tied-ridge-furrow with inorganic fertilizer on grain yield. The objectives of this study were (1) to quantify the responses of grain yield to fertilizer and mulching and establish the yield-fertilizer or mulching use relationship on the Loess Plateau and (2) to compare the effects of different tied-ridge-furrow systems with or without fertilizer and mulching methods on yield. To achieve these objectives, the PRISMA guideline (Moher et al., 2009) was used to perform a meta-analysis on related literature to determine the effect of inorganic fertilizer in tied-ridge-furrow on grain yield and soil physical properties. 
117

118

119

120

121

122

123

124

125

126

127

128

129

130

131

132

133

134

135

136

137

138

139

140

141

142

143

144

145

146

147

148

149

150

151

152

153

154

\section{Materials \& Methods}

Data collection

Scope of peer-reviewed papers

Peer-reviewed papers published in English between 2000 and 2020 that investigated the effects of tied-ridge-furrow with or without mulching or fertilizer on field crops were retrieved from online databases (ISI Web of Science, PubMed, Google Scholar, Scopus (Elsevier), JSTOR, and Science Direct) as previously described in Mak-Mensah et al. (2021). More than one database was used to minimize selection bias.

\section{Literature search strategy}

The literature search for the meta-analysis (MA) was done using the following keywords: 'rainwater harvesting', and/or 'ridge furrow', and/or 'tied ridge', and/or 'mulching' and/or 'yield'. The search yielded 101 publications, which were screened based on the following inclusion criteria: (1) on-field experimentation with at least ridge-furrow, tied-ridge-furrow, mulched ridges, fertilizer, flat planting, and no mulch treatments; (2) experimental fields recorded were located in rain-fed semiarid agricultural areas, and (3) crop yield was reported.

\section{Inclusion and exclusion criteria}

Based on the inclusion criteria, 85 of the papers found were excluded from this metaanalysis. As such, 16 papers were subjected to the study (Table 1). The publication screening procedure was adapted from the PRISMA meta-analysis protocol and is illustrated in a flowchart (Figure 1) (Moher et al., 2009).

\section{Heterogeneity occurrences and uncertainties}

Heterogeneities may have occurred from the following factors: (1) the researchers had different preferences and personal experiences; (2) many of the field experiments did not include any long-term observations; (3) the experimental fields exhibited different yield statuses, mulching and fertilizer application rates before sowing; and (4) field management practices and climatic conditions differed during crop-growing seasons. Although the effect of tied-ridgefurrow with fertilizer and mulching can be evaluated through meta-analytical method, underlying sources of meta-analytical uncertainties require further research. Figure 2, figure 3 and figure 4 depict locations of field experiments for studies included in the MA. The data from selected papers were classified based on biophysical parameters determined (Table 2). Table 3 shows mean, range, and coefficient of variation (CV) of yield for millet (Pennisetum glaucum) and sorghum (Sorghum bicolor) in different ridge-furrow rainwater harvesting practices with or without mulching and fertilizer, while Table 4 shows locations and precipitations.

Peer) reviewing PDF | (2021:04:59828:3:1:NEW 9 Jul 2021) 


\section{Statistical analysis and meta-analysis}

The importance of publications examined in this analysis was determined using the Newcastle Ottawa Scale (NOS) (Zeng et al., 2015). A 7-point scale was used to assess highquality publications (papers). The NOS scores ranged from 6 to 9 on a scale of one to ten (Table 1). Since more precise measurements have a greater effect on the overall sample ( $\mathrm{Yu}$ et al., 2018), results from research with more accurate measurements are given more weight.

We used construction confidence interval analysis to correlate the severity of the response ratio between the ridge-furrow, tied-ridge-furrow, and flat planting treatments (Gao et al., 2019). According to Gao et al. (2019) and Qin et al. (2015), we measured the effect size as the normal $\log (\ln \mathrm{R})$ of the response ratio $(\mathrm{R})$ which reflects the severity of the effect of ridge-furrow and tied-ridge-furrow on yield in this meta-analysis (Hedges et al., 1999), equation 1:

$$
\begin{aligned}
& \mathrm{R}=\theta_{\mathrm{t}} / \theta_{\mathrm{c}}, \\
& \operatorname{InR}=\operatorname{In}\left(\theta_{\mathrm{t}} / \theta_{\mathrm{c}}\right)=\operatorname{In} \theta_{\mathrm{t}}-\operatorname{In} \theta_{\mathrm{c}},
\end{aligned}
$$

where $\theta_{\mathrm{t}}$ and $\theta_{\mathrm{c}}$ are mean values of yield in tied-ridge-furrow and flat planting, respectively. According to $\mathrm{Li}$ et al. (2018), yield percentage change (Z) was calculated to further validate results of this study:

$$
\mathrm{Z}=(\mathrm{R}-1) \times 100 \%
$$

where a negative percentage change indicates a decrease in tied-ridge-furrow variable when compared to flat planting, and a positive percentage change indicates an increase in the corresponding variable when compared to flat planting. Subsequently, in addition to the means, sample sizes of the variables and standard deviation (SD) were extracted from the papers or estimated using the equation (Yu et al., 2018):

$$
\mathrm{SD}=\mathrm{SE} \times \sqrt{\mathrm{n}}
$$

For studies that did not record SD, average coefficient of variation (CV) within each data set was calculated, and the unavailable SD was approximated using the following equation $(\mathrm{Yu}$ et al., 2018):

$$
\mathrm{SD}=\mathrm{CV} \tilde{\mathrm{A}}-\theta
$$

where $\theta$ is average of flat or tied-ridge-furrow planting with mulch or fertilizer. Since effect sizes of tied-ridge-furrow with mulching or fertilizer and flat planting for crop yield are continuous variables, random-effects models were implemented using the Nordic Cochrane Centre's Review Manager Program (RevMan; ver. 5.3, Denmark). The heterogeneity between studies was assessed in this analysis using $\mathrm{Chi}^{2}$ and $I^{2}$ statistics (Table 4). The $I^{2}$ test value of: $\mathrm{I}^{2}$ $<25 \%$ indicates no heterogeneity, $25-75 \%$ indicates mild heterogeneity, and $\mathrm{I}^{2}>75 \%$ indicates high heterogeneity (Table 4) (Higgins, 2003). In cases with mild to high heterogeneity ( $\mathrm{Chi}^{2} \mathrm{p}$ - 
189

190

191

192

193

194

195

196

197

198

199

200

201

202

203

204

205

206

207

208

209

210

211

212

213

214

215

216

217

218

219

220

221

222

223

224

225

226

227

228

value $<0.05$ and $\mathrm{X}^{2}>50 \%$ ), a random-effects model was used. The ridge-furrow, tied-ridgefurrow with fertilizer, tied-ridge-furrow with mulching, and flat planting groups' mean differences were weighted according to their SE and sample sizes, and their confidence intervals (CI) were calculated from their weighted effect sizes. When there was no zero in the $95 \%$ CIs of the effect size of treatment, the impact of that treatment was significant. Concurrently, when the 95\% CIs contain zero, the treatment was not significant. To demonstrate distribution symmetries of individual experiments, frequency distribution of effect sizes (Odds ratio) was calculated using an Excel 2010 spreadsheet.

\section{Results \\ General characterization of findings}

Literature search yielded 101 publications (papers), which were screened based on inclusion and exclusion criteria and 16 papers were subjected to the study. China was the only Asian country examined in this study. African countries considered in this study were Ethiopia and Nigeria. This MA focused on the influence of tied-ridge-furrow as a viable method for increasing crop yield. The studies considered in this MA examined sorghum and millet production in Asia and Africa under temperatures $>20^{\circ} \mathrm{C}$, precipitation $>500 \mathrm{~mm}$, soil organic matter $<10, \mathrm{pH}>6$ to 7 , soil organic carbon $<9 \mathrm{~g} \mathrm{~kg}^{-1}$, total nitrogen $<50 \mathrm{mg} \mathrm{kg}^{-1}$, phosphorus $<20 \mathrm{mg} \mathrm{kg}^{-1}$, field capacity $>25 \%$, and permanent wilting point $>10$. Furthermore, soil textures considered in this MA were sandy and sandy loam soils (light), loamy sand and loam soils (medium), and clay loam, silty clay and clay soils (heavy). Data from most studies analyzed were in tables thus were transferred into the database of this MA directly.

\section{Influence of tied-ridge-furrow system with organic mulching on crop yield}

Through a synthesis of existing results, the current study examined impacts of tied-ridgefurrow with inorganic fertilizer on grain yield. Literature search yielded 101 publications (papers), which were screened based on inclusion and exclusion criteria and 16 papers were subjected to the study. China was the only Asian country examined in this study. African countries considered in this study were Ethiopia and Nigeria. In Ethiopia, sorghum is produced in almost all areas occupying an estimated cumulative land area of 1.68 million ha with national average yield of $2369 \mathrm{~kg} \mathrm{ha}^{-11}$. However, most soils are low in fertility mainly due to nutrient mining as about $\mathrm{K}\left(27.3 \mathrm{~kg} \mathrm{ha}^{-1}\right), \mathrm{P}\left(5.9 \mathrm{~kg} \mathrm{ha}^{-1}\right)$, and $\mathrm{N}\left(22.5 \mathrm{~kg} \mathrm{ha}^{-1}\right)$ per annum are lost from pearl millet production. In Nigeria, rainfall unpredictability and recent variations in weather conditions threatens crop yield and farmers income. Since this condition is not different from Ethiopia, a drought tolerant and high yielding sorghum variety, PAN 8625 is widely grown, with an average yield of $5533.83 \mathrm{~kg} \mathrm{ha}^{-1}$. The MA showed that tied-ridge-furrow with mulching is mainly practiced in Africa (Ethiopia and Nigeria) where temperatures are mostly greater than $20^{\circ} \mathrm{C}$ (Table 4). Results from the studies revealed there was no significant difference between grain yields in tied-ridge-furrow with mulching compared to flat planting $(p=0.48)$. Since mulches have a major impact on soils they are applied to, the absence of a significant difference 
229

230

231

232

233

234

235

236

237

238

239

240

241

242

243

244

245

246

247

248

249

250

251

252

253

254

255

256

257

258

259

260

261

262

263

264

265

266

267

268

is most likely attributable to the mulching materials used in those tests. The mulching materials used in these studies were guinea grass (Panicum maximum) which was applied on the ridges at $21,600 \mathrm{~kg} \mathrm{ha}^{-1}$ and $0.2 \mathrm{~m}$ thick and covered with $75 \%$ of soil after crop propagation and grass mulch applied at $10 \mathrm{~cm}$ thickness.

\section{Yield response of sorghum in tied-ridge-furrow without mulching or fertilizer}

When compared to flat planting, increase in sorghum yield in tied-ridge-furrow without mulching or fertilizer fields was significant. In 14 study observations, tied-ridge-furrow with no fertilizer or mulching applied treatment yielded 17\% sorghum grains greater than flat planting. Sorghum yield had an effect size of 1197.92 [551.25, 1844.60] with a p-value of 0.05 (Figure 5). This may be because soil organic carbon $\left(9 \mathrm{~g} \mathrm{~kg}^{-1}\right)$ has increased significantly $(p<0.0001)$ in this region. The $I^{2}$ test for sorghum yield in this MA yielded a value of 5\%, which was less than $25 \%$, suggesting that the studies used in this analysis were not heterogeneous. The randomeffects model was therefore used because $\mathrm{Chi}^{2} p$-value was $<0.05$. However, concerning precipitation, temperature, $\mathrm{pH}$, total nitrogen, phosphorus, soil texture, and soil organic matter, there was no significant difference $(p>0.05)$ in crop yield in these regions.

\section{Yield response of millet in tied-ridge-furrow system with inorganic fertilizer applications}

The yield of millet increased $20-40 \%$ in Africa (Ethiopia and Nigeria) from 18 study observations in tied-ridge-furrow with fertilizer application as compared to tied-ridge-furrow without mulching or fertilizer treatments (Figure 5). The effect size of the overall study effect ( $p$ $=0.03$ ) was $469.87[57.75,881.99]$. The $I^{2}$ for this comparison is $0 \%$, indicating that there is no heterogeneity among the studies included in this study. This might be due to the significant increase in total nitrogen $(13-42 \%)$ in the soil at $<50 \mathrm{mg} \mathrm{kg}^{-1}$ quantity which had an effect size of 469.14 [65.60, 872.67]. With an effect size of 469.14 [65.60, 872.67], yields in soils with heavy texture (clay loam, silt clay, and clay soils) also increased significantly. This subgroup also had $0 \%$ in $I^{2}$ test, which may have affected the substantial increase in soil organic matter in the area. In this MA, effect size of soil organic matter was 469.87 [57.75, 881.99]. However, concerning precipitation, temperature, $\mathrm{pH}$, total nitrogen, and phosphorus, there was no significant difference in crop yield in these regions.

\section{Discussion}

The current study examined impacts of tied-ridge-furrow with inorganic fertilizer and mulching on grain yield through a synthesis of 16 existing publication results. In this MA, crop yield had no significant difference between tied-ridge-furrow with mulching and flat planting (Refer to Table 4), which is consistent with Ndlangamandla et al. (2016), who found no major differences in sorghum yield between tied-ridge-furrow with mulching and flat planting. According to Demoz (2016), this negative effect is probably due to high soil temperatures created within the ridge which can be detrimental to seed germination, and shallow infiltration of moisture into the soil compared to that on flat soil when rainfall is light. Variations in seasonal 
269

270

271

272

273

274

275

276

277

278

279

280

281

282

283

284

285

286

287

288

289

290

291

292

293

294

295

296

297

298

299

300

301

302

303

304

305

306

307

308

rainfall can significantly affect crop yields (Silungwe et al., 2019). Tied ridges produce rectangular pools between ridges, increasing surface retention capacity and reducing runoff, resulting in improved soil moisture content and, as a result, crop development and yields. In Zimbabwe, Motsi et al. (2004) discovered that tied-ridge-furrow increased soil moisture compared to regular tillage, particularly during the dry months. Guzha (2004) in a similar study discovered that higher soil moisture was held in ridges and that; this was connected with higher roughness due to ridge shape. In addition, Silungwe et al. (2019) discovered that tied ridges hold soil moisture and increase yields more than flat planting in rain-fed agriculture. Consequently, Belachew \& Abera (2014) found that planting maize in tied ridge furrows increased maize yield by $32.3 \%$ as compared to flat planting.

However, according to Yoseph (2014b), even though Cowpea (Vigna Unguiculata L.) yield and yield components were not significantly affected by moisture conservation practices in their experimental study, yield advantage of tied-ridge-furrow was $26 \%$ compared to flat planting. The grain yield of pearl millet (Pennisetum glaucum) obtained from tied-ridge-furrow (3634 $\mathrm{kg} \mathrm{ha}^{-1}$ ) was higher by $12.52 \%$ compared to farmers' practice (3179 $\mathrm{kg} \mathrm{ha}^{-1}$ ) (Yoseph, 2014b). In contrast to flat planting, this MA showed a substantial increase in sorghum yield in tied-ridge-furrow without mulching or fertilizer plots (Refer to Figure 5). This is consistent with findings of Adeboye et al. (2017), who found that tied-ridge-furrow rainwater harvesting practices increased grain yield by $14.0-41.8 \%$ relative to flat planting. According to McHugh et al. (2007), tied-ridge-furrow and no-till significantly reduced seasonal soil loss by up to 11,000 $\mathrm{kg} \mathrm{ha}^{-1}$ during seasons with moderate intensity storms. Similar research by Netsere et al. (2015) discovered that compared to flat planting and untied ridge, tied-ridge-furrow increased Arabica Coffee yield by 19.0-23.6\%. Local farmers who practiced tied-ridge-furrow realized a statistically significant $(p<0.05)$ difference in yields of about $3,000 \mathrm{~kg} \mathrm{ha}^{-1}$ compared to flat planting whose yields were about $1,500 \mathrm{~kg} \mathrm{ha}^{-1}$ (Motsi et al., 2004). In another study by Zelelew et al. (2018), tied-ridge-furrow provided the highest grain yield of $2300 \mathrm{~kg} \mathrm{ha}^{-1}$ compared to flat planting which gave a yield of $1750 \mathrm{~kg} \mathrm{ha}^{-1}$ in the dry season. Again, Milkias et al. (2018) investigated in-situ rainwater harvesting field experiments over two years and reported a significant increase of $143.14 \%$ in maize grain yield due to increased soil moisture storage by tied-ridge-furrow compared to flat planting treatment. Tied ridges have higher moisture content at $0-5 \mathrm{~cm}$ and 6-10 $\mathrm{cm}$ depths than flat planting (Mandumbu et al., 2020).

Conversely, Gerbu (2015) reported that field experiments had a yield advantage of 56 $68 \%$ in improved varieties with fertilizer and tied-ridge-furrow treatments compared to flat planting of local sorghum cultivar without fertilizer as an attractive option to boost sorghum yield under moisture stress environment. According to this MA, millet grain yield increased by 20 to $40 \%$ in tied-ridge-furrow treatments with fertilizer application compared to tied-ridgefurrow without mulching or fertilizer treatments (Refer to Figure 5). Results here consolidate previous findings of Aleminew et al. (2020), who found highest grain yield (3355 and $3145 \mathrm{~kg}$ $\mathrm{ha}^{-1}$ ) for pearl millet, with application of micro-dose fertilizer with dry seed in tied-ridge-furrow and recommended fertilizer rate with dry seed in tied-ridge-furrow, respectively. In similar 
research, Gebrekidan (2003) found highest yield increment of $1361 \mathrm{~kg} \mathrm{ha}^{-1}(34.5 \%)$ due to tiedridge-furrow compared with flat planting on Entisols with NP followed by $1255 \mathrm{~kg} \mathrm{ha}^{-1}(48.5 \%)$ on Alemaya black clay soils (Vertisols) under fertilized conditions, indicating that yield response to water conservation treatments was higher under fertilized than under unfertilized conditions on the two soils. Accordingly, maximum sorghum grain yield $\left(3226.70-4621.00 \mathrm{~kg} \mathrm{ha}^{-1}\right)$ under fertilized and (2678.00 - $\left.4318.80 \mathrm{~kg} \mathrm{ha}^{-1}\right)$ unfertilized conditions were obtained from closed tiedridge-furrow with planting in-furrow (Sibhatu et al., 2017). In addition, for maize, they found that highest grain yield (4414 and $4392 \mathrm{~kg} \mathrm{ha}^{-1}$ ) recorded was with the application of micro-dose fertilizer with primed seed in tied ridge with intercropping mung bean and recommended fertilizer rate with dry seed in tied-ridge-furrow (Aleminew et al., 2020). This according to Biazin \& Stroosnijder (2012), might be due to tied-ridge-furrow with fertilizer being more effective in improving crop yields during seasons with low rainfall events $(280-330 \mathrm{~mm})$. Meanwhile, most farmers in semi-arid areas, due to risk of crop failure and poor harvests emanating from periodic water shortages, investing in fertilizers (and other inputs) is simply not worthwhile (Rockström et al., 2002). This leaves them in low-risk, low-yield and low-income agriculture (Dercon \& Christiaensen, 2011). Therefore, alleviating agricultural water deficiency through the use of tied-ridge-furrow may give farmers the conviction to invest in soil enhancement practices (fertilizers or biochar) for improved crop production in rain-fed regions. The authors suggested the use of tied-ridge-furrow with fertilizer application to enhance crop yield thus developing a global agricultural scheme capable of meeting up with food safety and at the same time, achieve economic, social, and environmental sustainability (Okpala, 2020).

\section{Conclusions}

Given the poor soil fertility level of semiarid areas in Asia and Africa, a single intervention through rainwater harvesting techniques may not bring a substantial impact on crop productivity. Based on the results of this study, it can be concluded that tied-ridge-furrow rainwater harvesting system with fertilizer application retains soil moisture and could be adopted by farmers in semiarid areas to increase crop yields. While there was no substantial difference in crop yield in tied-ridge-furrow with mulching treatment compared to flat planting, there was a significant increase in sorghum yield in tied-ridge-furrow without mulching or fertilizer fields compared to flat planting. In view of yields of sorghum and millet increased significantly in tiedridge-furrow without mulching or fertilizer treatment compared to flat planting and tied-ridgefurrow with fertilizer treatment compared with tied-ridge-furrow without mulching or fertilizer treatment, respectively, this study recommend the use of fertilizers with tied-ridge-furrow system to increase yield in semiarid areas compared to flat planting. The study recommends more research on tied-ridge-furrow systems with other organic mulches and fertilizers in semiarid areas.

\section{References}

Adeboye OB, Schultz B, Adekalu KO, Prasad K. 2017. Soil water storage, yield, water 
productivity, and transpiration efficiency of soybeans ( Glyxine max L.Merr ) as affected by soil surface management in Ile-Ife, Nigeria. International Soil and Water Conservation Research 5:141-150. DOI: 10.1016/j.iswcr.2017.04.006.

Ademe D, Bekele B, Gebremichael A. 2018. On-farm Verification of the Soil Moisture and Yield Response of Tied Ridge on Maize Production in Dry Areas of SNNPR, Ethiopia. Journal of Environment and Earth Science ISSN 8(5), 1-5.

Aleminew A, Tadesse T, Merene Y, Bayu W, Dessalegn Y. 2020. Effect of integrated technologies on the productivity of maize, sorghum, and pearl millet crops for improving resilience capacity to climate change effects in the drylands of Eastern Amhara, Ethiopia. Cogent Food \& Agriculture 6(1):1728084. DOI: 10.1080/23311932.2020.1728084.

Andrew Tapiwa K. 2019. Effects of Integrated Nutrient Management and Water Harvesting Technique (Tied Ridges) on Grain and Stover Yields of Pearl Millet. Acta Scientific Microbiology 2:33-38. DOI: 10.31080/asmi.2019.02.0297.

Antala M, Sytar O, Rastogi A, Brestic M. 2020. Potential of karrikins as novel plant growth regulators in agriculture. Plants 9:1-13. DOI: 10.3390/plants9010043.

Bährle-Rapp M. 2007. Diammonium Phosphate. In: Springer Lexikon Kosmetik und Körperpflege. Berlin, Heidelberg: Springer Berlin Heidelberg, 152-152. DOI: 10.1007/9783-540-71095-0_2853.

Belachew T, Abera Y. 2014. Response of maize ( Zea mays L .) to tied ridges and planting methods at Goro, Southeastern Ethiopia. American-Eurasian Journal of Agronomy 3(1):2124.

Berhanu T, Beshir W, Lakew A. 2020. Effect of Integrated Technologies on Production and Productivity of Pearl Millet in the Dryland Areas of Wag Himira Administrative Zone, Eastern Amhara, Ethiopia. International Journal of Agronomy 2020:1-5. DOI: $10.1155 / 2020 / 4381870$.

Biazin B, Stroosnijder L. 2012. To tie or not to tie ridges for water conservation in Rift Valley drylands of Ethiopia. Soil and Tillage Research 124:83-94. DOI: 10.1016/j.still.2012.05.006.

Brhane G, Wortmann CS, Mamo M, Gebrekidan H, Belay A. 2006. Micro-basin tillage for grain sorghum production in semiarid areas of Northern Ethiopia. Agronomy Journal 98:124-128. DOI: 10.2134/agronj2005-0148.

Demoz HA. 2016. A Review on Effect of Tie Ridging on Crop Productivity in Dry. 6:1-6.

Deng XP, Shan L, Zhang H, Turner NC. 2006. Improving agricultural water use efficiency in arid and semiarid areas of China. Agricultural Water Management 80:23-40. DOI: 10.1016/j.agwat.2005.07.021.

Dercon S, Christiaensen L. 2011. Consumption risk, technology adoption and poverty traps: Evidence from Ethiopia. Journal of Development Economics 96:159-173. DOI: 10.1016/j.jdeveco.2010.08.003.

Dong W, Zhang L, Duan Y, Sun L, Zhao P, van der Werf W, Evers JB, Wang Q, Wang R, Sun Z. 2017. Ridge and furrow systems with film cover increase maize yields and mitigate 
401

402

403

404

405

406

407

408

409

410

411

412

413

414

415

416

417

418

419

420

421

422

423

424

425

426

427

428

climate risks of cold and drought stress in continental climates. Field Crops Research 207:71-78. DOI: 10.1016/j.fcr.2017.03.003.

Eldoma IM, Li M, Zhang F, Li F-M. 2016. Alternate or equal ridge-furrow pattern: Which is better for maize production in the rain-fed semi-arid Loess Plateau of China? Field Crops Research 191:131-138. DOI: 10.1016/j.fcr.2016.02.024.

Gao H, Yan C, Liu Q, Ding W, Chen B, Li Z. 2019. Effects of plastic mulching and plastic residue on agricultural production: A meta-analysis. Science of The Total Environment 651:484-492. DOI: 10.1016/j.scitotenv.2018.09.105.

Gebrekidan H. 2003. Grain yield response of sorghum (Sorghum bicolor) to tied ridges and planting methods on entisols and vertisols of Alemaya area, eastern Ethiopian highlands. Journal of Agriculture and Rural Development in the Tropics and Subtropics 104:113-128.

Gerbu LH. 2015. On-Farm Evaluation of Sorghum ( Sorghum bicolor L . Moench ) Varieties Under Tie Ridge and NP Fertilizer at Mekeredi, Moisture Stress Area of Amaro, Southern Ethiopia. Agricultural and Biological Sciences Journal 1:37-41.

Grum B, Assefa D, Hessel R, Woldearegay K, Kessler A, Ritsema C, Geissen V. 2017. Effect of In Situ Water Harvesting Techniques on Soil and Nutrient Losses in Semi-Arid Northern Ethiopia. Land Degradation and Development 28:1016-1027. DOI: 10.1002/ldr.2603.

Guzha AC. 2004. Effects of tillage on soil microrelief, surface depression storage and soil water storage. Soil and Tillage Research 76:105-114. DOI: 10.1016/j.still.2003.09.002.

Hashem A, Kumar A, Al-Dbass AM, Alqarawi AA, Al-Arjani ABF, Singh G, Farooq M, Abd_Allah EF. 2019. Arbuscular mycorrhizal fungi and biochar improve drought tolerance in chickpea. Saudi Journal of Biological Sciences 26:614-624. DOI: 10.1016/j.sjbs.2018.11.005.

Hedges L V., Gurevitch J, Curtis PS. 1999. The meta-analysis of response ratios in experimental ecology. Ecology $80: 1150-1156 . \quad$ DOI: $\quad 10.1890 / 0012-$ 9658(1999)080[1150:TMAORR]2.0.CO;2.

Higgins JPT. 2003. Measuring inconsistency in meta-analyses. BMJ 327:557-560. DOI: 10.1136/bmj.327.7414.557.

Jensen J., Bernhard R., Hansen S, McDonagh J, Møberg J., Nielsen N., Nordbo E. 2003. Productivity in maize-based cropping systems under various soil-water-nutrient management strategies in a semi-arid, alfisol environment in East Africa. Agricultural Water Management 59:217-237. DOI: 10.1016/S0378-3774(02)00151-8.

Kuznetsov EA, Passot T, Sulem PL. 2008. Nonlinear theory of mirror instability near its threshold. JETP letters, 86(10), 637-642. DOI: 10.1134/S0021364007220055.

Li Q, Li H, Zhang L, Zhang S, Chen Y. 2018. Mulching improves yield and water-use efficiency of potato cropping in China: A meta-analysis. Field Crops Research 221:50-60. DOI: 10.1016/j.fcr.2018.02.017.

Liu C-A, Siddique KHM. 2015. Does Plastic Mulch Improve Crop Yield in Semiarid Farmland at High Altitude? Agronomy Journal 107:1724-1732. DOI: 10.2134/agronj15.0052.

Luo Z, Wang E, Sun OJ. 2010. Can no-tillage stimulate carbon sequestration in agricultural 
soils? A meta-analysis of paired experiments. Agriculture, Ecosystems and Environment 139:224-231. DOI: 10.1016/j.agee.2010.08.006.

Mak-Mensah E, Obour PB, Essel E, Wang Q, Ahiakpa JK. 2021. Influence of plastic film mulch with biochar application on crop yield, evapotranspiration, and water use efficiency in northern China: A meta-analysis. PeerJ 9:e10967. DOI: 10.7717/peerj.10967.

Mandumbu R, Nyawenze C, Rugare JT, Nyamadzawo G, Parwada C, Tibugari H. 2020. Tied Ridges and Better Cotton Breeds for Climate Change Adaptation. African Handbook of Climate Change Adaptation:1-15. DOI: 10.1007/978-3-030-42091-8_23-1.

McHugh O V., Steenhuis TS, Berihun Abebe, Fernandes ECM. 2007. Performance of in situ rainwater conservation tillage techniques on dry spell mitigation and erosion control in the drought-prone North Wello zone of the Ethiopian highlands. Soil and Tillage Research 97:19-36. DOI: 10.1016/j.still.2007.08.002.

Milkias A, Tadesse T, Zeleke H. 2018. Evaluating the Effects of In-situ Rainwater Harvesting Techniques on Soil Moisture Conservation and Grain Yield of Maize (Zea mays L.) in Fedis District, Eastern Hararghe, Ethiopia. Turkish Journal of Agriculture - Food Science and Technology 6:1129. DOI: 10.24925/turjaf.v6i9.1129-1133.1839.

Mo F, Wang J-Y, Xiong Y-C, Nguluu SN, Li F-M. 2016. Ridge-furrow mulching system in semiarid Kenya: A promising solution to improve soil water availability and maize productivity. European Journal of Agronomy 80:124-136. DOI: 10.1016/j.eja.2016.07.005.

Moher D, Liberati A, Tetzlaff J, Altman DG, Altman D, Antes G, Atkins D, Barbour V, Barrowman N, Berlin JA, Clark J, Clarke M, Cook D, D’Amico R, Deeks JJ, Devereaux PJ, Dickersin K, Egger M, Ernst E, Gøtzsche PC, Grimshaw J, Guyatt G, Higgins J, Ioannidis JPA, Kleijnen J, Lang T, Magrini N, McNamee D, Moja L, Mulrow C, Napoli M, Oxman A, Pham B, Rennie D, Sampson M, Schulz KF, Shekelle PG, Tovey D, Tugwell P. 2009. Preferred reporting items for systematic reviews and meta-analyses: The PRISMA statement. PLoS Medicine 6(7): e1000097. DOI: 10.1371/journal.pmed.1000097.

Motsi KE, Chuma E, Mukamuri BB. 2004. Rainwater harvesting for sustainable agriculture in communal lands of Zimbabwe. Physics and Chemistry of the Earth 29:1069-1073. DOI: 10.1016/j.pce.2004.08.008.

Ndlangamandla MT, Ndlela ZP, Manyatsi AM. 2016. Mulching and Tied Ridges as A Moisture Conservation Strategy to Improve the Yield of Sorghum ( Sorghum Bicolor ) in Semi-Arid Parts of Swaziland. International Journal of Environmental \& Agriculture Research (IJOEAR) 2:23-26.

Netsere A, Kufa T, Tesfaye S. 2015. Review of Arabica coffee management research in Ethiopia. Journal of Biology, Agriculture and Healthcare 5:235-258.

Okpala COR. 2020. Toward Sustaining Global Food Systems for the Future. Frontiers in Sustainable Food Systems 4:1-4. DOI: 10.3389/fsufs.2020.00003.

Olsovska K, Kovar M, Brestic M, Zivcak M, Slamka P, Shao HB. 2016. Genotypically identifying wheat mesophyll conductance regulation under progressive drought stress. Frontiers in Plant Science 7:1-14. DOI: 10.3389/fpls.2016.01111. 
469

470

471

472

473

474

475

476

477

478

479

480

481

482

483

484

485

486

487

488

489

490

491

492

493

494

495

496

497

498

499

500

501

502

503

504

505

506

507

508

Pan Y, Pan X, Zi T, Hu Q, Wang J, Han G, Wang J, Pan Z. 2019. Optimal Ridge-Furrow Ratio for Maximum Drought Resilience of Sunflower in Semi-Arid Region of China. Sustainability 11:4047. DOI: 10.3390/su11154047.

Qin W, Hu C, Oenema O. 2015. Soil mulching significantly enhances yields and water and nitrogen use efficiencies of maize and wheat: a meta-analysis. Scientific Reports 5:16210. DOI: $10.1038 /$ srep 16210 .

Ren X, Chen X, Cai T, Wei T, Wu Y, Ali S, Zhang P, Jia Z. 2017. Effects of Ridge-Furrow System Combined with Different Degradable Mulching Materials on Soil Water Conservation and Crop Production in Semi-Humid Areas of China. Frontiers in Plant Science 8. DOI: 10.3389/fpls.2017.01877.

Rockström J, Barron J, Fox P. 2002. Rainwater management for increased productivity among small-holder farmers in drought prone environments. Physics and Chemistry of the Earth 27:949-959. DOI: 10.1016/S1474-7065(02)00098-0.

Sibhatu B, Berhe H, Gebrekorkos G, Abera K. 2017. Effect of Tied Ridging and Fertilizer on the Productivity of Sorghum [Sorghum Bicolor (L.)Moench] at Raya Valley, Northern Ethiopia. Current Agriculture Research Journal 5:396-403. DOI: 10.12944/carj.5.3.20.

Silungwe F, Graef F, Bellingrath-Kimura S, Tumbo S, Kahimba F, Lana M. 2019. Analysis of Intra and Interseasonal Rainfall Variability and Its Effects on Pearl Millet Yield in a Semiarid Agroclimate: Significance of Scattered Fields and Tied Ridges. Water (Switzerland) 11:578. DOI: 10.3390/w11030578.

Song Z, Guo J, Zhang Z, Kou T, Deng A, Zheng C, Ren J, Zhang W. 2013. Impacts of planting systems on soil moisture, soil temperature, and corn yield in rainfed areas of Northeast China. European Journal of Agronomy 50:66-74. DOI: 10.1016/j.eja.2013.05.008.

Verheijen F, Jeffery S, Bastos AC, Van Der Velde M, Diafas I. 2010. Biochar Application to Soils: A Critical Scientific Review of Effects on Soil Properties, Processes and Functions. EUR, 24099, 162. DOI: 10.2788/472.

Wang TC, Wei L, Wang HZ, Ma SC, Ma BL. 2011. Responses of rainwater conservation, precipitation-use efficiency, and grain yield of summer maize to a furrow-planting and straw-mulching system in northern China. Field Crops Research 124:223-230. DOI: 10.1016/j.fcr.2011.06.014.

Wang YP, Li XG, Hai L, Siddique KHM, Gan Y, Li FM. 2014. Film fully-mulched ridge-furrow cropping affects soil biochemical properties and maize nutrient uptake in a rainfed semi-arid environment. Soil Science and Plant Nutrition 60:486-498. DOI: 10.1080/00380768.2014.909709.

Wolka K, Mulder J, Biazin B. 2018. Effects of soil and water conservation techniques on crop yield, runoff and soil loss in Sub-Saharan Africa: A review. Agricultural Water Management 207:67-79. DOI: 10.1016/j.agwat.2018.05.016.

Xiukang W, Zhanbin L, Yingying X. 2015. Effects of mulching and nitrogen on soil temperature, water content, nitrate-N content, and maize yield in the Loess Plateau of China. Agricultural Water Management 161:53-64. DOI: 10.1016/j.agwat.2015.07.019.

Peer) reviewing PDF | (2021:04:59828:3:1:NEW 9 Jul 2021) 
509

510

511

512

513

514

515

516

517

518

519

520

521

522

523

524

525

526

527

528

529

530

531

532

533

534

535

536

537

538

539

540

Yan N, Wu B, Perry C, Zeng H. 2015. Assessing potential water savings in agriculture on the Hai Basin plain, China. Agricultural Water Management 154:11-19. DOI: 10.1016/j.agwat.2015.02.003.

Yoseph T. 2014a. Performance Evaluation of Cowpea ( Vigna unguiculata L .) Varieties Under Moisture Conservation Practices for Yield and Yield Components at Alduba, Southern Ethiopia. International Journal of Research in Agricultural Sciences 4:7-12.

Yoseph T. 2014b. Evaluation of Moisture Conservation Practices, Inter and Intra Row Spacing on Yield and Yield Components of Pearl Millet ( Pennisetum glaucum ) at Alduba, Southern Ethiopia. Journal of Natural Sciences Research 4:79-85.

$\mathrm{Yu}$ Y, Jia H, Zhao C. 2018. Evaluation of the effects of plastic mulching and nitrapyrin on nitrous oxide emissions and economic parameters in an arid agricultural field. Geoderma 324:98-108. DOI: 10.1016/j.geoderma.2018.03.012.

Yu Y-Y, Turner NC, Gong Y-H, Li F-M, Fang C, Ge L-J, Ye J-S. 2018. Benefits and limitations to straw- and plastic film mulch on maize yield and water use efficiency: A meta-analysis across hydrothermal gradients. European Journal of Agronomy 99:138-147. DOI: 10.1016/j.eja.2018.07.005.

Zelelew DG, Ayimute TA, Melesse AM. 2018. Evaluating the Response of In Situ Moisture Conservation Techniques in Different Rainfall Distributions and Soil-Type Conditions on Sorghum Production and Soil Moisture Characteristics in Drought-Prone Areas of Northern Ethiopia. Water Conservation Science and Engineering 3:157-167. DOI: 10.1007/s41101018-0045-7.

Zeng X, Zhang Y, Kwong JSW, Zhang C, Li S, Sun F, Niu Y, Du L. 2015. The methodological quality assessment tools for preclinical and clinical studies, systematic review and metaanalysis, and clinical practice guideline: A systematic review. Journal of Evidence-Based Medicine 8:2-10. DOI: 10.1111/jebm.12141.

Zhang F, Zhang W, Qi J, Li FM. 2018. A regional evaluation of plastic film mulching for improving crop yields on the Loess Plateau of China. Agricultural and Forest Meteorology 248:458-468. DOI: 10.1016/j.agrformet.2017.10.030.

Zheng J, Fan J, Zou Y, Chau HW, Zhang F. 2019. Ridge-furrow plastic mulching with a suitable planting density enhances rainwater productivity, grain yield, and economic benefit of rainfed maize. Journal of Arid Land, 12, 181-198. DOI: 10.1007/s40333-019-0032-7.

Peer) reviewing PDF | (2021:04:59828:3:1:NEW 9 Jul 2021) 


\section{Table 1 (on next page)}

Study areas, crops and literature sources used in this meta-analysis

NOS stands for Newcastle Ottawa Scale 
1 Table 1. Study areas, crops and literature sources used in this meta-analysis

\begin{tabular}{|c|c|c|c|c|c|}
\hline References & Cardinal point (N,E, m a.s.I) & Crops & Location & Country & NOS \\
\hline Berhanu et al., 2020 & $12^{\circ} 68^{\prime}, 39^{\circ} 15^{\prime}, 1976$ & \multirow[t]{2}{*}{ Pearl millet } & Sekota & Ethiopia & 8 \\
\hline Aleminew et al., 2020 & $39^{\circ} 63^{\prime}, 12^{\circ} 15^{\prime}, 1512$ & & Kobo & Ethiopia & 7 \\
\hline Sibhatu et al., 2017 & $12^{\circ} 41^{\prime} 50^{\prime \prime}, 39^{\circ} 42^{\prime} 08^{\prime \prime}, 1578$ & \multirow{3}{*}{ Sorghum } & Fachagama & Ethiopia & 9 \\
\hline Zelelew et al., 2018 & $39^{\circ} 04^{\prime}, 12^{\circ} 63^{\prime}, 2254$ & & Sekota & Ethiopia & 7 \\
\hline Brhane et al., 2006 & $138^{\circ} 14^{\prime} 06^{\prime \prime}, 388^{\circ} 58^{\prime} 50^{\prime \prime}, 1500$ & & Abergelle & Ethiopia & 6 \\
\hline Grum et al., 2017 & $13^{\circ} 52^{\prime} 49^{\prime \prime}, 39^{\circ} 28^{\prime} 59^{\prime \prime}, 2408$ & \multirow{2}{*}{ Maize } & Gule & Ethiopia & 6 \\
\hline Ademe et al., 2018 & N/A & & Sankurra & Ethiopia & 8 \\
\hline Adeboye et al., 2017 & $70^{\circ} 33^{\prime} 0^{\prime \prime}, 40^{\circ} 34^{\prime} 0^{\prime \prime}, 271$ & Soybeans & Ile-Ife & Nigeria & 9 \\
\hline Pan et al., 2019 & $41^{\circ} 08^{\prime} 22.8^{\prime \prime}, 111^{\circ} 17^{\prime} 43.6^{\prime \prime}, 1589$ & Sunflower & Wuchuan & China & 6 \\
\hline Dong et al., 2017 & $43^{\circ} 33^{\prime}$ and $125^{\circ} 38^{\prime} / 42^{\circ} 30^{\prime}, 118^{\circ} 88^{\prime}$ & \multirow{7}{*}{ Maize } & Shuangyang (Jilin/ Chifeng) & China & 7 \\
\hline Ren et al., 2017 & $35^{\circ} 15^{\prime}, 110^{\circ} 18^{\prime}, 850$ & & Ganjing & China & 8 \\
\hline Xiukang et al., 2015 & $35^{\circ} 12^{\prime}, 107^{\circ} 40^{\prime}, 1206$ & & Changwu & China & 9 \\
\hline Liu and Siddique, 2015 & $36^{\circ} 02^{\prime}, 104^{\circ} 25^{\prime}, 2400$ & & Zhonglianchuan & China & 6 \\
\hline Song et al., 2013 & $43^{\circ} 30^{\prime} 23,124^{\circ} 48^{\prime} 34,220$ & & Gongzhuling & China & 6 \\
\hline Wang et al., 2011 & $113^{\circ} 39^{\prime}, 34^{\circ} 43^{\prime}, 111.3$ & & Zhengzhou & China & 7 \\
\hline Wang et al., 2014 & $35^{\circ} 29^{\prime}, 107^{\circ} 45^{\prime}, 1264$ & & Ningxian & China & 7 \\
\hline
\end{tabular}

${ }^{a}$ NOS stands for Newcastle Ottawa Scale 


\section{Table 2 (on next page)}

Categorization of data within the selected publications

(A) 500 (low mean precipitation); $500 \mathrm{~mm}$ (high mean precipitation); ${ }^{(B)} 10^{\circ} \mathrm{C}$ (low mean temperature); $10-20{ }^{\circ} \mathrm{C} ; 20^{\circ} \mathrm{C}$ (high mean temperature); (C) $9 \mathrm{~g} / \mathrm{kg}$ (low organic $\mathrm{C}$ content); 9 $\mathrm{g} / \mathrm{kg}$ (high organic C content); ${ }^{(D)} 1.3$ (low soil bulk density) $\mathrm{g} \mathrm{cm}^{-3} ; 1.3 \mathrm{~g} \mathrm{~cm}^{-3}$ (high soil bulk density); ${ }^{(E)} 5$ (acidic pH); Neutral: pH; 6-7, acidic: pH 5-6, very, 7-8 (slightly alkaline) ${ }^{\text {(F) }} 50$ (low soil available $\mathrm{N}$ ) $\mathrm{mg} \mathrm{kg}^{-1} ; 50 \mathrm{mg} \mathrm{kg}^{-1}$ (high soil available $\mathrm{N}$ ); ${ }^{(\mathrm{G})} 20$ (low soil available P) $\mathrm{mg} \mathrm{kg}^{-1} ; 20 \mathrm{mg} \mathrm{kg}^{-1}$ (high soil available P); ${ }^{(\mathrm{H})} 25 \%$ (low FC); $25 \%$ (high FC) 
Table 2. Categorization of data within the selected publications

\begin{tabular}{|c|c|c|c|c|c|c|c|c|c|}
\hline $\begin{array}{l}\text { Annual mean } \\
\text { precipitation }\end{array}$ & $\begin{array}{l}\text { Annual air } \\
\text { temperature }\end{array}$ & $\begin{array}{c}\text { Organic C } \\
\text { content }\end{array}$ & $\begin{array}{c}\text { Soil bulk } \\
\text { density }(0-20 \\
\mathrm{cm}) \\
\end{array}$ & $\begin{array}{l}\text { Soil texture }(0- \\
20 \mathrm{~cm})\end{array}$ & $\mathrm{pH}$ & $\begin{array}{c}\text { Soil } \\
\text { available N }\end{array}$ & $\begin{array}{c}\text { Soil } \\
\text { available P }\end{array}$ & $\mathrm{FC}$ & $\begin{array}{c}\text { Tillage } \\
\text { management }\end{array}$ \\
\hline$\leq 500 \mathrm{~mm}$ & $<10^{\circ} \mathrm{C}$ & $<9 \mathrm{~g} / \mathrm{kg}$ & $\begin{array}{r}<1.3 \\
\mathrm{~g} \mathrm{~cm}^{-3}\end{array}$ & $\begin{array}{l}\text { Light: sandy } \\
\text { and sandy loam } \\
\text { soils }\end{array}$ & $\begin{array}{c}\text { Very } \\
\text { acidic: } \\
\text { pH }<5\end{array}$ & $\begin{array}{c}<50 \\
\mathrm{mg} \mathrm{kg}^{-1}\end{array}$ & $\begin{array}{c}<20 \\
\mathrm{mg} \mathrm{kg}^{-1}\end{array}$ & $\begin{array}{c}<150 \\
\mathrm{mg} \mathrm{kg}^{-1}\end{array}$ & $\begin{array}{l}\mathrm{RF} \text {, ridge-- } \\
\text { furrow; }\end{array}$ \\
\hline \multirow[t]{3}{*}{$>500 \mathrm{~mm}$} & $10-20^{\circ} \mathrm{C}$ & $>9 \mathrm{~g} / \mathrm{kg}$ & $\begin{array}{l}>1.3 \\
\mathrm{~g} \mathrm{~cm}^{-3}\end{array}$ & $\begin{array}{l}\text { Medium: loamy } \\
\text { sand and loam } \\
\text { soils }\end{array}$ & $\begin{array}{l}\text { Acidic: } \\
\text { pH 5-6 }\end{array}$ & $\begin{array}{c}>50 \\
\mathrm{mg} \mathrm{kg}^{-1}\end{array}$ & $\begin{array}{c}>20 \\
\mathrm{mg} \mathrm{kg}^{-1}\end{array}$ & $\begin{array}{c}>150 \\
\mathrm{mg} \mathrm{kg}^{-1}\end{array}$ & $\begin{array}{l}\text { TRFS, tied } \\
\text { ridge- } \\
\text { furrow with } \\
\text { fertilizer; }\end{array}$ \\
\hline & $>20{ }^{\circ} \mathrm{C}$ & & & $\begin{array}{c}\text { Heavy: clay } \\
\text { loam, silty clay, } \\
\text { and clay soils }\end{array}$ & $\begin{array}{l}\text { Neutral: } \\
\text { pH 6-7 }\end{array}$ & & & & $\begin{array}{l}\text { TRFP, tied } \\
\text { ridge-- } \\
\text { furrow with } \\
\text { mulching }\end{array}$ \\
\hline & & & & & $\begin{array}{l}\text { Slightly } \\
\text { alkaline: } \\
>7\end{array}$ & & & & \\
\hline
\end{tabular}

$2 \quad$ a $<500$ (low mean precipitation); $>500 \mathrm{~mm}$ (high mean precipitation);

$3 \mathrm{~b}^{\mathrm{b}}<10^{\circ} \mathrm{C}$ (low mean temperature); $10-20{ }^{\circ} \mathrm{C} ;>20{ }^{\circ} \mathrm{C}$ (high mean temperature);

$4 \quad c<9 \mathrm{~g} / \mathrm{kg}$ (low organic $\mathrm{C}$ content); $>9 \mathrm{~g} / \mathrm{kg}$ (high organic $\mathrm{C}$ content);

$5 \mathrm{~d}<1.3$ (low soil bulk density) $\mathrm{g} \mathrm{cm}^{-3} ;>1.3 \mathrm{~g} \mathrm{~cm}^{-3}$ (high soil bulk density);

6 e $<5$ (acidic $\mathrm{pH}$ ); Neutral: $\mathrm{pH} ;>6-7$, acidic: $\mathrm{pH}$ 5-6, very, $>$ 7-8 (slightly alkaline)

7 f $<50$ (low soil available $\mathrm{N}$ ) $\mathrm{mg} \mathrm{kg}^{-1} ;>50 \mathrm{mg} \mathrm{kg}^{-1}$ (high soil available $\mathrm{N}$ );

$8 \mathrm{~g}<20$ (low soil available $\mathrm{P}$ ) $\mathrm{mg} \mathrm{kg}^{-1} ;>20 \mathrm{mg} \mathrm{kg}^{-1}$ (high soil available P);

$9 \mathrm{~h} \leq 25 \%$ (low FC); $>25 \%$ (high FC) 


\section{Table 3(on next page)}

Mean, range, and coefficient of variance (CV) of grain yield in the various tillage systems with fertilizer and mulching combinations 
1 Table 3. Mean, range, and coefficient of variance (CV) of grain yield in the various tillage 2 systems with fertilizer and mulching combinations

\begin{tabular}{|c|c|c|c|c|}
\hline Treatment & Mean & Total & Range & $\mathrm{CV}$ \\
\hline \multirow[t]{2}{*}{ Tied ridge with mulching } & 2610.0 & 2 & - & - \\
\hline & 2155.0 & 2 & $2110-2200$ & 2.95 \\
\hline \multirow[t]{4}{*}{ Tied ridge with fertilizer } & 3157.2 & 2 & $2851-3463$ & 9.69 \\
\hline & 3896.1 & 5 & $2537.6-5653$ & 30.81 \\
\hline & 2790.0 & 2 & - & - \\
\hline & 3846.2 & 2 & $3153.4-4539$ & 25.47 \\
\hline \multirow[t]{7}{*}{ Tied ridge } & 2622.0 & 2 & $1831-3413$ & 42.66 \\
\hline & 2743.2 & 5 & $2648-2839.8$ & 2.67 \\
\hline & 3394.0 & 2 & $2653.6-4134.5$ & 30.85 \\
\hline & 1914.2 & 2 & $1680-2540$ & 28.82 \\
\hline & 2685.0 & 2 & $2500-2870$ & 9.74 \\
\hline & 8350.0 & 4 & $7700-9000$ & 6.52 \\
\hline & 1415.0 & 3 & $860.3-2301.8$ & 54.84 \\
\hline \multirow[t]{7}{*}{ Ridge-furrow with mulching } & 12277.5 & 4 & 8026-14021 & 23.37 \\
\hline & 1456.7 & 3 & $0-2742$ & 94.67 \\
\hline & 9480.5 & 4 & $8217-10601$ & 11.65 \\
\hline & 3364.9 & 3 & $3330.7-3407.2$ & 1.16 \\
\hline & 8564.0 & 2 & 3726-13402 & 79.89 \\
\hline & 6863.8 & 2 & $6142-7585.6$ & 14.87 \\
\hline & 7043.3 & 3 & $5440-8600$ & 22.44 \\
\hline \multirow[t]{5}{*}{ Ridge-furrow } & 11247.3 & 4 & $6581-13140$ & 27.76 \\
\hline & 1079.7 & 3 & $0-2005$ & 93.67 \\
\hline & 6850.5 & 2 & $414-13287$ & 132.87 \\
\hline & 10670.0 & 3 & $8503.3-11949.6$ & 17.68 \\
\hline & 5933.3 & 2 & $4941-6925.5$ & 23.65 \\
\hline \multirow[t]{13}{*}{ Flat planting } & 9758.8 & 4 & 5014-11660 & 32.70 \\
\hline & 1036.3 & 3 & $0-2231$ & 108.45 \\
\hline & 8246.0 & 4 & $7255-8844$ & 8.87 \\
\hline & 3711.4 & 3 & $3627.1-3795.7$ & 2.27 \\
\hline & 6747.0 & 2 & $378-13116$ & 133.50 \\
\hline & 10419.8 & 3 & 8543.6-11614.7 & 15.79 \\
\hline & 5503.2 & 2 & $4805-6201.4$ & 17.94 \\
\hline & 6600.0 & 3 & $6190-6940$ & 5.76 \\
\hline & 1988.0 & 4 & $1061-3339$ & 51.80 \\
\hline & 2954.4 & 10 & $1789.6-4086$ & 27.26 \\
\hline & 2805.0 & 2 & - & - \\
\hline & 2901.4 & 4 & $2107.7-3870.4$ & 28.65 \\
\hline & 1600.0 & 2 & $1560-1640$ & 3.54 \\
\hline
\end{tabular}




\begin{tabular}{cccc}
1135.0 & 2 & $790-1480$ & 42.99 \\
6150.0 & 4 & $5400-6600$ & 8.55 \\
750.5 & 3 & $0-1749.1$ & 119.99 \\
\hline
\end{tabular}

3

4 


\section{Table 4(on next page)}

Heterogeneity analysis on grain yield under flat planting compared to tied ridge, tied ridge compared to tied ridge with fertilizer, and flat planting compared to tied ridge with mulching using random-effects models 
Tables 4. Heterogeneity analysis on grain yield under flat planting compared to tied ridge, tied ridge compared to tied ridge with

2 fertilizer, and flat planting compared to tied ridge with mulching using random-effects models

\begin{tabular}{|c|c|c|c|c|c|c|c|c|}
\hline \multirow[b]{2}{*}{ Tillage combinations } & \multirow[b]{2}{*}{ Categories } & \multirow[b]{2}{*}{$\mathbf{n}$} & \multicolumn{5}{|c|}{ Heterogeneity } & \multirow[b]{2}{*}{ Overall effect (P) } \\
\hline & & & $\mathrm{Chi}^{2}$ & df & $\mathbf{P}$ & $I^{2 \%} \%$ & $\mathbf{Z}$ & \\
\hline \multirow{13}{*}{$\begin{array}{l}\text { Flat planting compared } \\
\text { to tied ridge }\end{array}$} & Africa & 20 & 34 & 6 & $<0.00001$ & 82 & 1.98 & 0.05 \\
\hline & Sorghum & 7 & 2.1 & 2 & 0.35 & 5 & 3.63 & 0.0003 \\
\hline & Millet & 7 & 0.75 & 1 & 0.39 & 0 & 0.62 & 0.54 \\
\hline & Temperature $\left(>20^{\circ} \mathrm{C}\right)$ & 6 & 0.12 & 2 & 0.94 & 0 & 1.15 & 0.25 \\
\hline & Precipitation $(>500 \mathrm{~mm})$ & 6 & 0.12 & 2 & 0.94 & 0 & 1.15 & 0.25 \\
\hline & Soil texture (Heavy) & 14 & 14.5 & 4 & 0.01 & 72 & 1.34 & 0.18 \\
\hline & Soil organic matter $(<10)$ & 7 & 0.75 & 1 & 0.39 & 0 & 0.62 & 0.54 \\
\hline & $\mathrm{pH}(>6-7)$ & 9 & 14.2 & 2 & 0 & 86 & 0.9 & 0.37 \\
\hline & Soil organic carbon $\left(<9 \mathrm{~g} \mathrm{~kg}^{-1}\right)$ & 4 & 0.8 & 1 & 0.37 & 0 & 3.91 & $<0.0001$ \\
\hline & Total Nitrogen $\left(<50 \mathrm{mg} \mathrm{kg}^{-1}\right)$ & 14 & 14.5 & 4 & 0.01 & 72 & 1.34 & 0.18 \\
\hline & Phosphorus $\left(<20 \mathrm{mg} \mathrm{kg}^{-1}\right)$ & 9 & 14.2 & 2 & 0 & 86 & 0.9 & 0.37 \\
\hline & Field capacity $(>25 \%)$ & 5 & 0.02 & 1 & 0.87 & 0 & 1.12 & 0.26 \\
\hline & Permanent wilting point $(>10)$ & 5 & 0.02 & 1 & 0.87 & 0 & 1.12 & 0.26 \\
\hline \multirow{9}{*}{$\begin{array}{l}\text { Tied ridge compared } \\
\text { to tied ridge with fertilizer }\end{array}$} & Africa & 9 & 0.6 & 2 & 0.74 & 0 & 2.28 & 0.02 \\
\hline & Millet & 7 & 0.6 & 1 & 0.44 & 0 & 2.23 & 0.03 \\
\hline & Temperature $\left(>20^{\circ} \mathrm{C}\right)$ & 4 & 0 & 1 & 0.97 & 0 & 1.91 & 0.06 \\
\hline & Precipitation $(>500 \mathrm{~mm})$ & 4 & 0 & 1 & 0.97 & 0 & 1.91 & 0.06 \\
\hline & Soil texture (Heavy) & 9 & 0.6 & 2 & 0.74 & 0 & 2.28 & 0.02 \\
\hline & Soil organic matter $(<10)$ & 7 & 0.6 & 1 & 0.44 & 0 & 2.23 & 0.03 \\
\hline & $\mathrm{pH}(>6-7)$ & 7 & 0.17 & 1 & 0.68 & 0 & 1.47 & 0.14 \\
\hline & Total Nitrogen $\left(<50 \mathrm{mg} \mathrm{kg}^{-1}\right)$ & 9 & 0.6 & 2 & 0.74 & 0 & 2.28 & 0.02 \\
\hline & Total Phosphorus $\left(<20 \mathrm{mg} \mathrm{kg}^{-1}\right)$ & 7 & 0.17 & 1 & 0.68 & 0 & 1.47 & 0.14 \\
\hline \multirow{3}{*}{$\begin{array}{l}\text { Flat planting compared } \\
\text { to tied ridge with mulching }\end{array}$} & Africa & 4 & 4.4 & 1 & 0.04 & 77 & 0.71 & 0.48 \\
\hline & Temperature $\left(>20^{\circ} \mathrm{C}\right)$ & 4 & 4.4 & 1 & 0.04 & 77 & 0.71 & 0.48 \\
\hline & Soil texture (Light) & 4 & 4.4 & 1 & 0.04 & 77 & 0.71 & 0.48 \\
\hline
\end{tabular}


Figure 1

Flowchart of literature identification, and screening for use in this study. Adapted from PRISMA (Moher et al., 2009) 

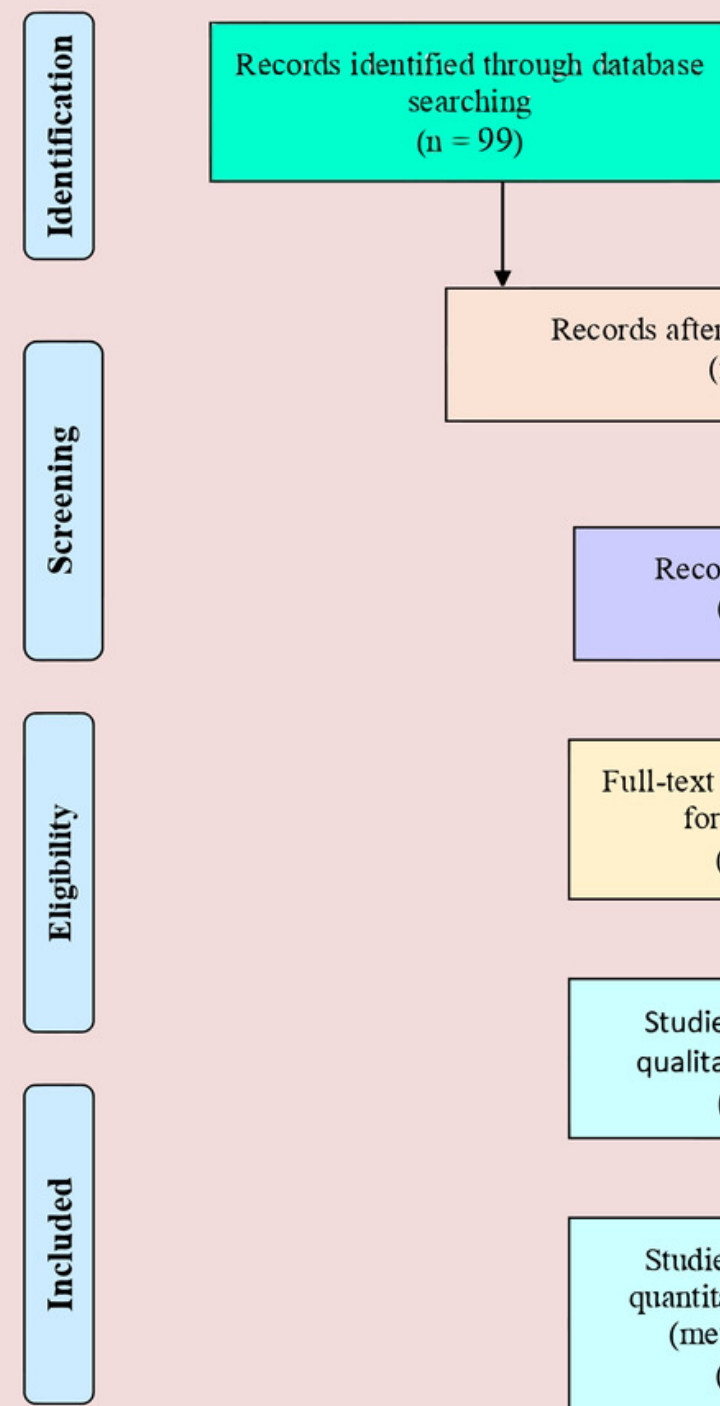

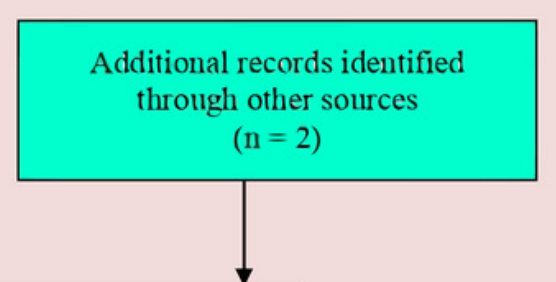

Records after duplicates removed

$$
(\mathrm{n}=100)
$$
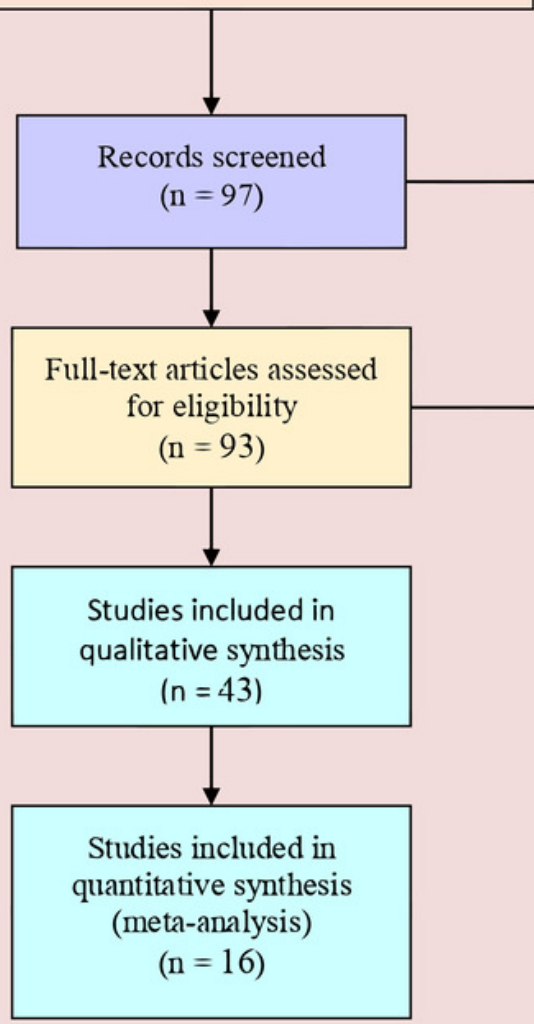

Full-text articles excluded, with reasons $(\mathrm{n}=50)$

Figure 1. Flowchart of literature identification, and screening for use in this study. Adapted from PRISMA (Moher et al., 2009). 
Figure 2

Experimental locations from the peer-reviewed publications in Ethiopia for the metaanalysis. ArcGIS 10.6 software (ESRI, Redlands, California) was used to produce the map.

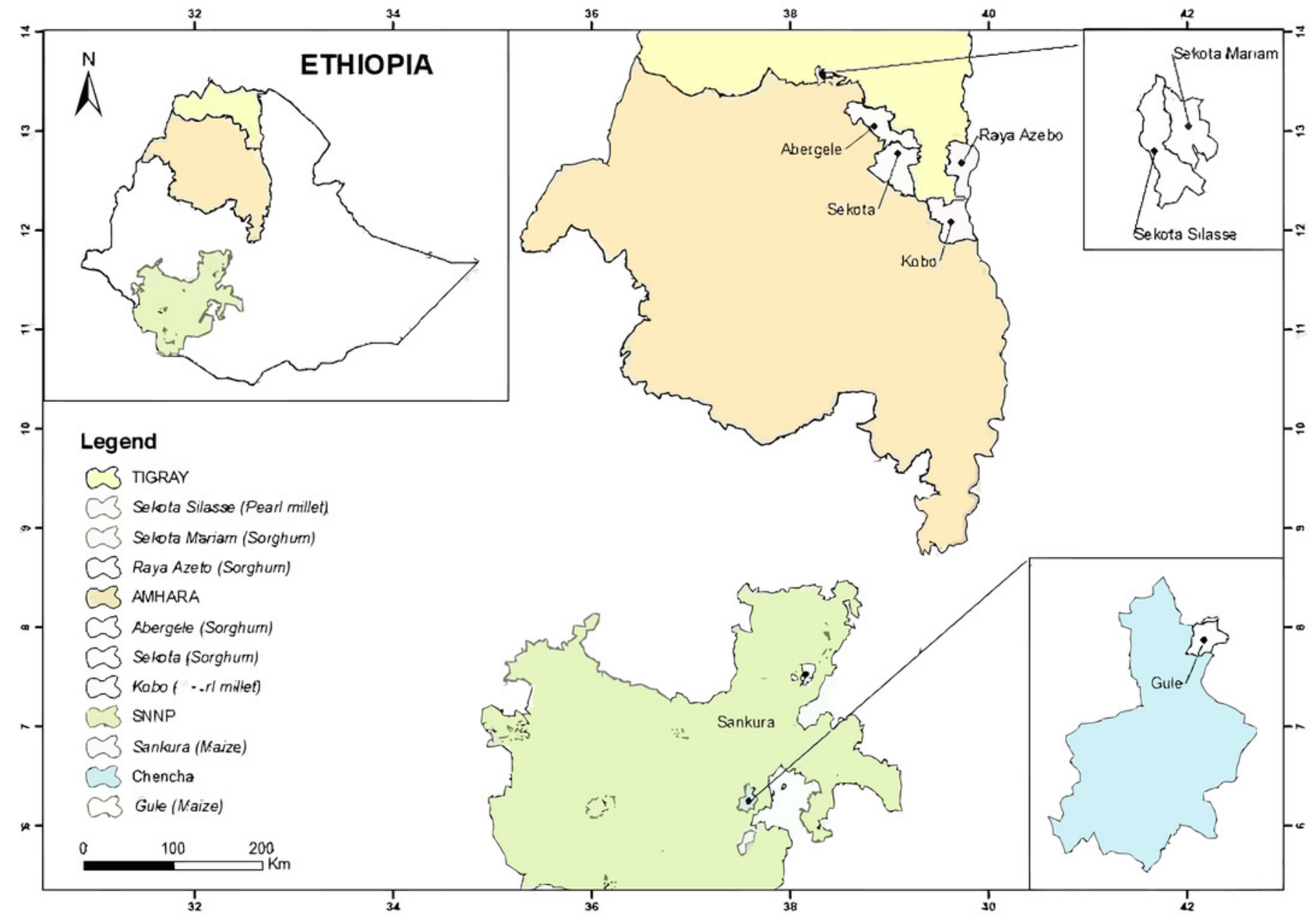


Figure 3

Experimental locations from the peer-reviewed publications in Nigeria for the metaanalysis. ArcGIS 10.6 software (ESRI, Redlands, California) was used to produce the map.

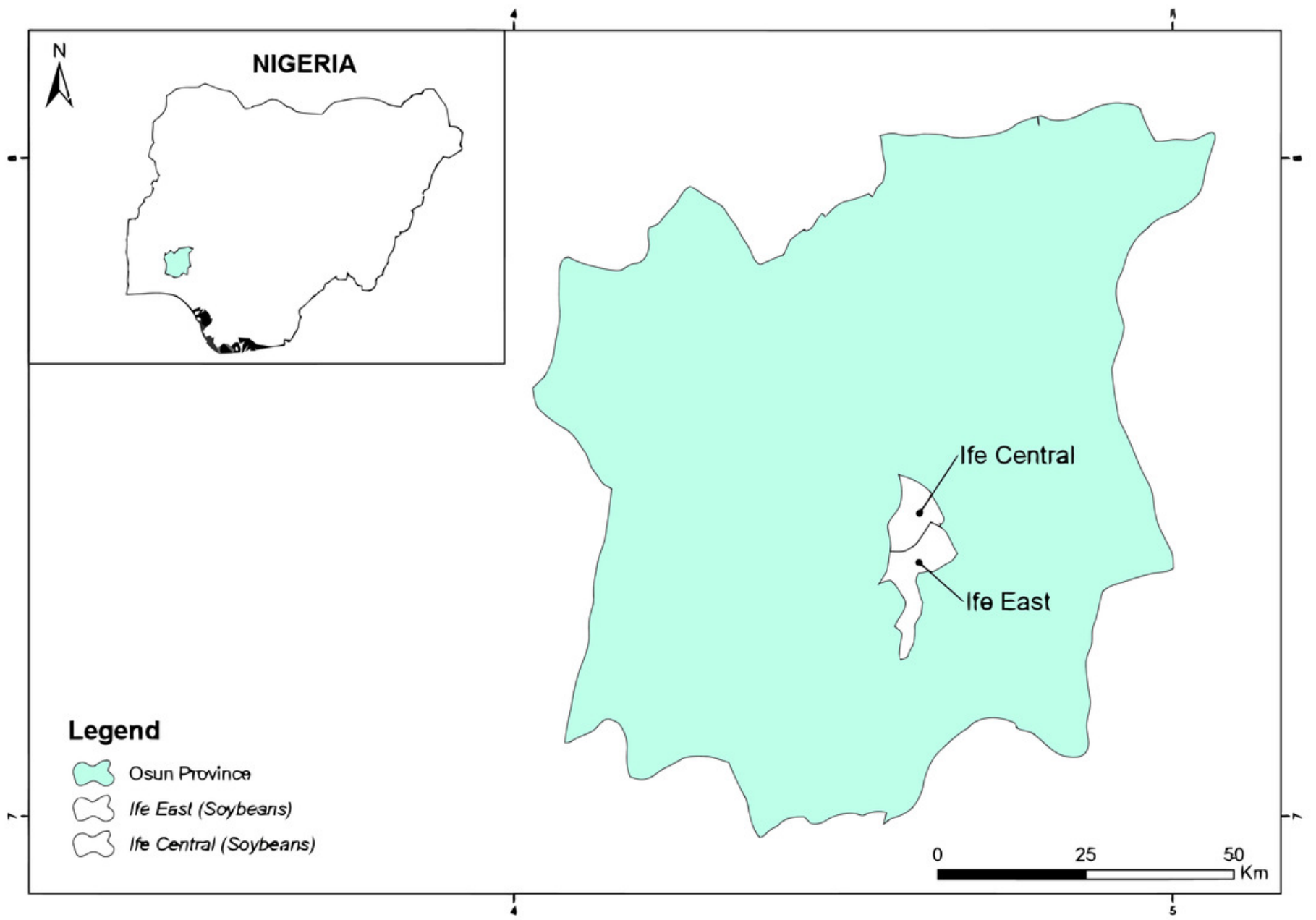


Figure 4

Experimental locations from the peer-reviewed publications in China for the metaanalysis. ArcGIS 10.6 software (ESRI, Redlands, California) was used to produce the map.

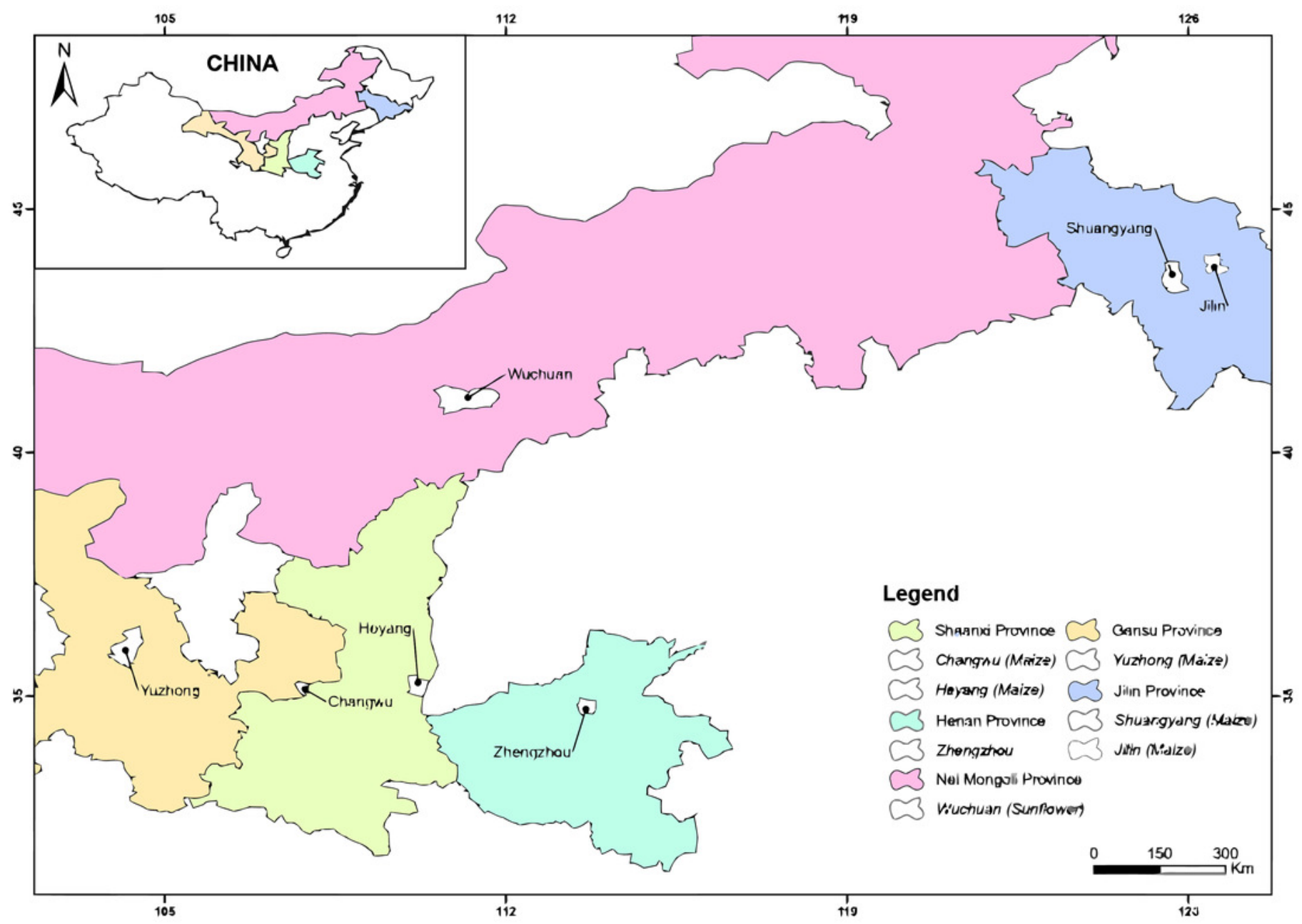




\section{Figure 5}

Odds ratios of crop yields in (A) flat planting compared to tied ridge. (B) tied ridge compared to tied ridge with fertilizer. The error bars signify $95 \%$ confidence intervals, and the values above the bars indicate the number of observations (n).

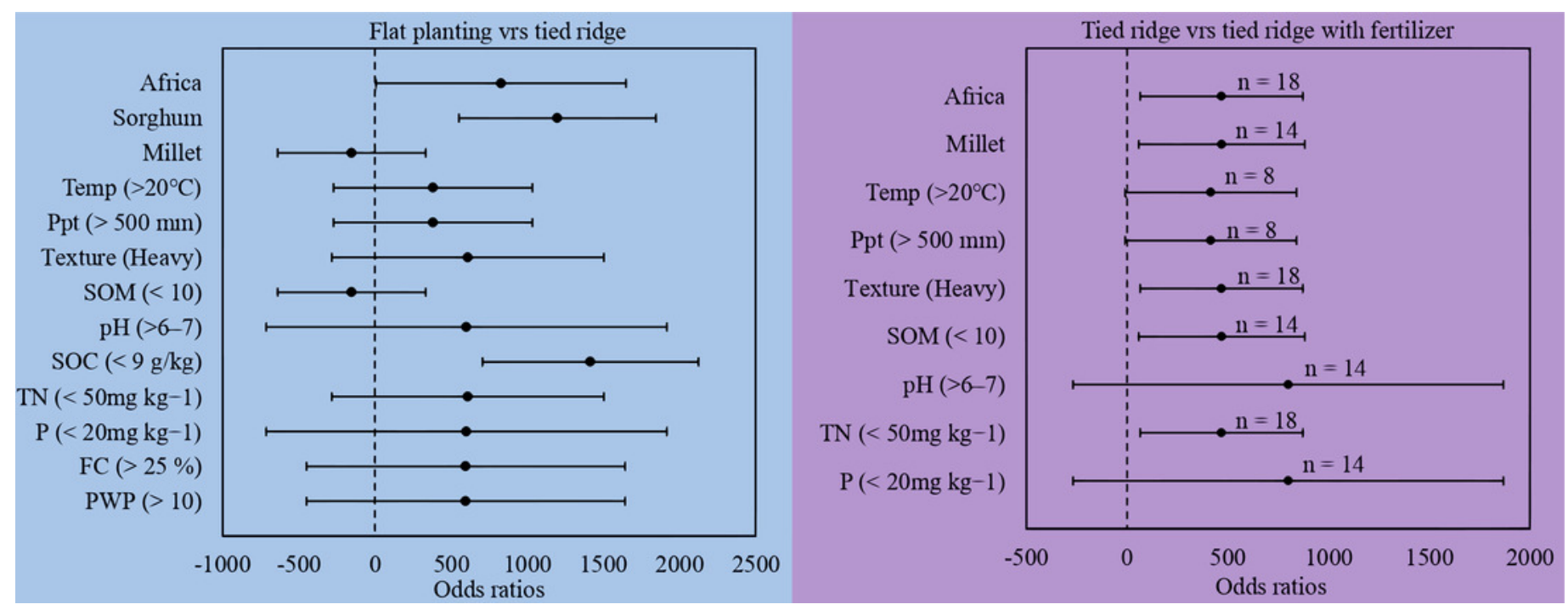

